\title{
Age and Correlation of the Clinchfield Sand in Georgia
}

By S. M. HERRICK

CONTRIBUTIONS TO STRATIGRAPHY

GEOLOGICA L S URVEY BULIETIN $1354-$ E

Basal upper Eocene (Jackson) formations at three localities were deposited in.shallow seas; Foraminifera were collected from each locality

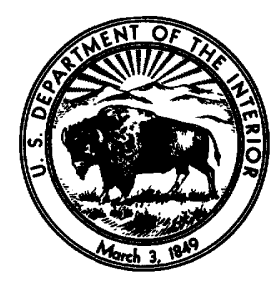




\section{UNITED STATES DEPARTMENT OF THE INTERIOR}

ROGERS G. B. MORTON, Secretary

\section{GEOLOGIGAL SURVEY}

W. A. Radlinski, Acting Director

Library of Congress catalog-card No. 72-184204

U.S. GOVERNMENT PRINTING OFFICE

WASHINGTON : 1972

For sale by the Superintendent of Documente, U.S. Government Printing Office Washington, D.C. 20402 - Price 15 cents

Stock Number 2401-2024 


\section{CONTENTS}

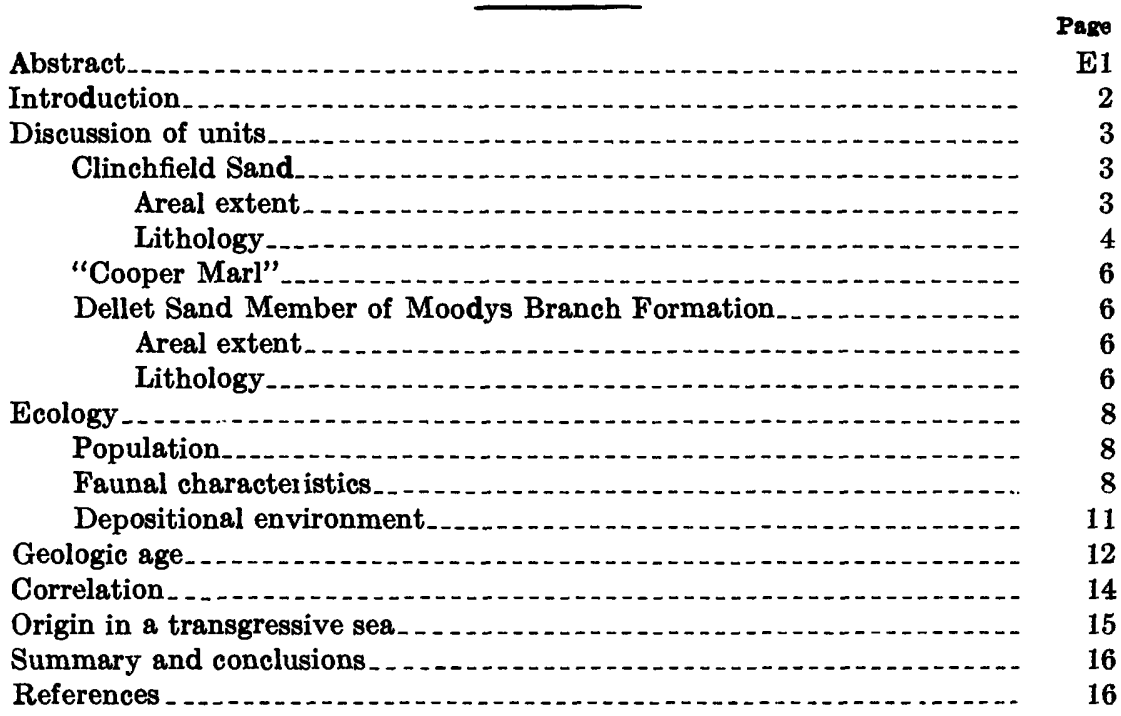

\section{ILLUSTRATIONS}

Frgure 1. Map of Georgia and Alabama showing approximate updip limit of Clinchfield Sand and Ocala Limestone.......... 2. Test hole in type section in west quarry of Penn-Dixie Cement Co., near Clinchfield, Ga. 3. Jackson-Claiborne section at Claiborne Bluff, Monroe County, Ala

\section{TABLE}

TABLE 1. Foraminifera of the Clinchfield Sand at Clinchfield, Ga., and its equivalents at Baldock, S.C., Claiborne Bluff, Ala., and Jackson, Miss 



\title{
AGE AND CORRELATION OF THE CLINCHFIELD SAND IN GEORGIA
}

\author{
By S. M. HerRick
}

\begin{abstract}
Formations at three localities-Claiborne Bluff, Ala., Baldock, S.C., and Clinchfield, Ga.-were deposited by a transgressive sea in early late Eocene (Jackson) time. The Jackson sea was widespread in southwestern Georgia, but in eastern Georgia it was restricted to a relatively narrow strip ending in the vicinity of Baldock, S.C.

The Clinchfield Sand, named by R. E. Carver in 1966 for the town of Clinchfield, Houston County, Ga., is herein adopted. Exposures are in the quarries of the Penn-Dixie Cement Co. and along Big Indian Creek, on Georgia Highway 247, 2.4 miles northwest of the Houston and Pulaski County line. The Clinchfield Sand generally underlies the Ocala Limestone and overlies the Lisbon Formation (equivalent to the McBean Formation) in south-central Georgia. The Clinchfield extends from the Chattahoochee River eastward across Georgia to the Savannah River.

The deposit at Claiborne Bluff, Ala., named by $H$. B. Stenzel in 1952 for the Dellet mansion, a landmark in the town of Claiborne, Monroe County, is herein adopted as the Dellet Sand Member of the Moodys Branch Formation and is identified as the equivalent of the Clinchfield Sand.

The deposit at Baldock, S.C., consists of a very sandy calcareous fossiliferous marl and is identified in this report by the term "Cooper Marl." The quotation marks are used to indicate that there was an error in the first published stratigraphic position of the marl at Baldock. The deposits at Clinchfield and Baldock represent very shallow seas, not more than 15-30 feet in depth. The sediments at Claiborne Bluff were deposited on the continental shelf in fairly shallow water, probably not more than 75-90 feet.

The basal upper Eocene (Jackson) deposits at the three localities are stratigraphically equivalent, though not identical. The deposits described from Clinchfield and Baldock representing a carbonate facies are more closely related to each other than to those from Claiborne Bluff.

This paper includes a list of Foraminifera collected at the three localities.
\end{abstract}




\section{INTRODUCTION}

Some large fossil oysters were collected in 1966 from an exposure of the Clinchfield Sand on the north edge of the east (old) quarry of the Penn-Dixie Cement Co., on the east side of U.S. Highway 341, 0.2 mile south of Clinchfield, Ga. The fossils were taken from a shelly reeflike deposit near the top of the unconsolidated Clinchfield Sand and about 1.5-2 feet below the base of the Ocala Limestone. The filling from one of the fossil oyster shells was subsequently removed and examined for Foraminifera by the writer.

As there was doubt regarding the specific identity of these fossil oysters, specimens were sent to $H$. B. Stenzel ${ }^{1}$ who advised further investigation of the Clichfield Sand to establish its possible correlation with the Dellet Sand (Dellet Sand Member of the Moodys Branch Formation), which he had named and described (Stenzel, 1952) at Claiborne Bluff, Monroe County, Ala. The writer visited Claiborne Bluff in February 1967 and collected samples from the Dellet. These samples were subsequently processed and examined for Foraminifera.

The writer noted the marked similarity between the fauna at Clinchfield and the fauna from a marl at Baldock, S.C., that Ruth Todd ${ }^{2}$ identified as late Eocene. (See list in report by Cooke and MacNeil, 1952 , p. 27.) Cooke $(1936$, p. 88$)$ referred the marl at Baldock to the "Cooper Marl," a formation now known to be Oligocene in age. The quotation marks around the term "Cooper Marl" are used to indicate an error in the original published stratigraphic position of the marl at Baldock, S.C.

The purposes of this paper are to present foraminiferal evidence of the early Jackson age of the Clinchfield Sand and to demonstrate its stratigraphic equivalence to the Dellet Sand Member of the Moodys Branch Formation and to the marl deposit at Baldock, S.C. The Foraminifera from the three localities are listed in table 1.

The name Clinchfield Sand was first used in a formal sense by Carver (1966). Herrick (1961) described a section in a well (GGS 339) consisting of 39 feet of Ocala Limestone and 10 feet of unnamed sand at base. The unnamed sand is now designated Clinchfield Sand. The type section (fig. 2) is 9 feet thick in a test hole (GGS 994 ${ }^{3}$ ) in the west (new) quarry of the Penn-Dixie Cement Co., near Clinchfield, Ga. The sand is exposed in the north side of the cement company's east (old) quarry. On the outcrop not more than 5-6 feet of sand is exposed in the quarry; the Big Indian Creek section is 10 feet thick.

\footnotetext{
${ }^{1}$ Professor, Department of Geology, Louisiana State University, Baton Rouge, La.

2 Paleontologist, U.S. Geological Survey, Washington, D.C.

3 Samples from this test hole are fled in the sample collection maintained by the Georgia Department of Mines, Mining and Geology.
} 


\section{DISCUSSION OF UNITS}

\section{CLINCHFIELD SAND}

\section{AREAL EXTENT}

The line $A-A^{\prime}$ (fig. 1) shows the approximate updip limit of the Ocala Limestone and the Clinchfield Sand that generally underlies it in updip areas. This line of demarcation is based on a study of well cuttings from many deep wells, on field observations, and on information obtained from published reports. Strictly speaking, however, the Clinchfield Sand crops out for fairly short distances-generally less than a mile-beyond the updip limit of the overlying Ocala Limestone. Nevertheless, line $A-A^{\prime}$ may be regarded as marking the updip limit of the two units.

Assuming that line $A-A^{\prime}$ is correct, it is evident that the sea in which these sediments were deposited was widespread in Georgia, particularly in the southwestern part. The occurrence of outliers, such as Rich Hill and Browns Mountain, for example, suggests that the Jackson sea was even more extensive than is indicated in figure 1. In

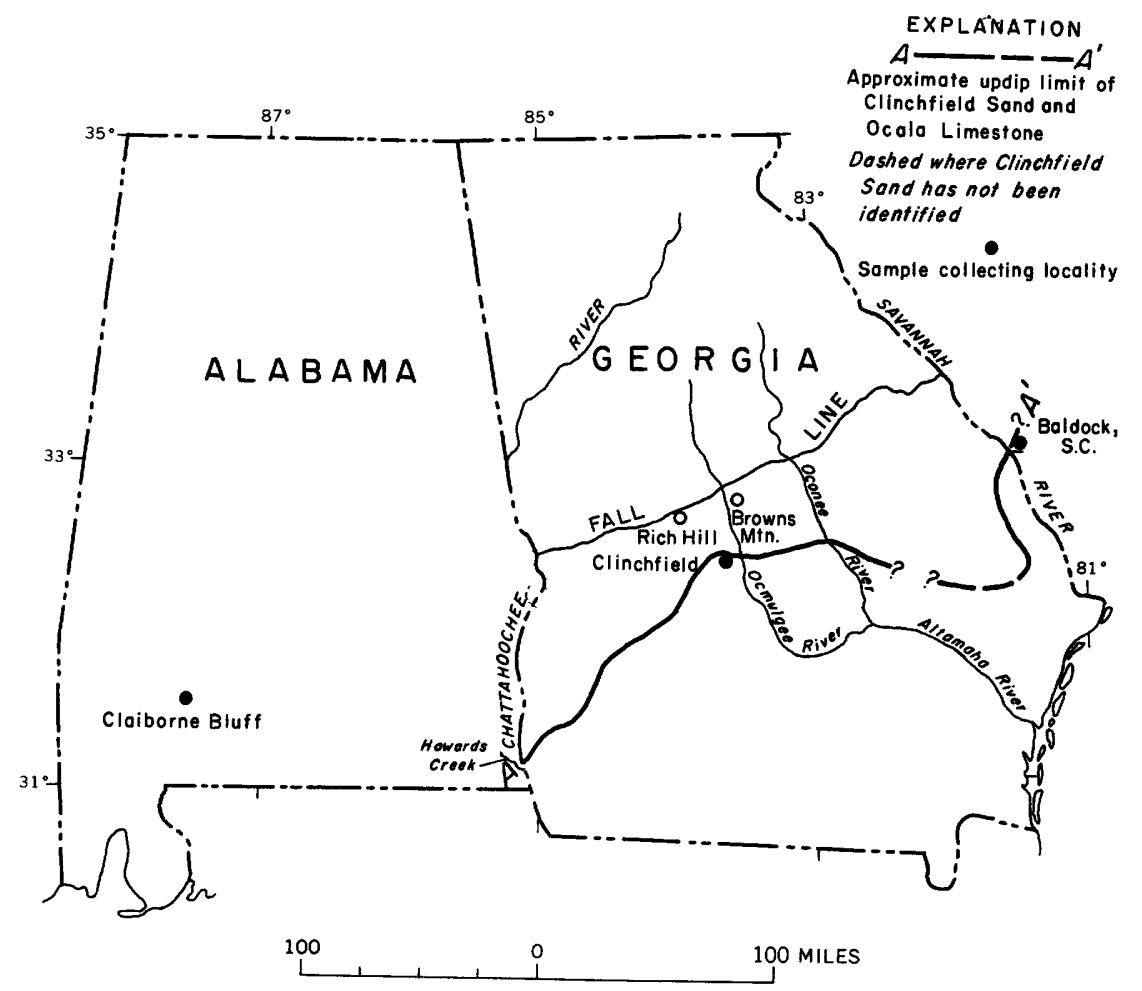

Figure 1.-Approximate updip limit of Clinchfield Sand and Ocala Limestone. 
eastern Georgia, as shown by a rather deep reentrant in line $A-A^{\prime}$, the Jackson sea was apparently restricted to a fairly narrow strip that trends inland in a northwestward direction and finally crosses the Savannah River in the vicinity of Baldock, S.C. Here it is thought that the Jackson sea was forced coastward by the presence of an anticlinal structure, the so-called "Great Carolina Ridge," which, according to Cooke $(1936$, p. 158), was formed during late Eocene time and hence was in existence during the deposition of the sediments at the three localities.

The Clinchfield Sand is believed to underlie much of the updip part of the Coastal Plain west of the Oconee River. For example, Vorhis (1972) has contoured the top of the Clinchfield Sand in Sumter, Crisp, Dooly, Lee, Pulaski, and Wilcox Counties, an area of about 1,800 square miles. East of the Oconee, however, the Clinchfield is concealed by geologically younger deposits; hence, it was identified in wells in the tonguelike extension trending inland in a northwestward direction that approximately parallels the Savannah River. In certain areas between this tonguelike extension and the Oconee River, the Clinchfield Sand has not been identified in wells (see broken line, fig. 1), though it probably occurs locally. Generally, in the subsurface downdip (south) of line $A-A^{\prime}$, the sand ultimately changes to limestone and becomes part of the Ocala Limestone.

\section{LITHOLOGY}

Figure 2 shows the section that exists below the limestone floor of the west quarry of the Penn-Dixie Cement Co., near Clinchfield, Ga. Here, the Ocala Limestone rests directly upon fine-grained Clinchfield Sand, which in turn overlies the Lisbon Formation (equivalent to the McBean Formation), a sandy lignitic brackish-water somewhat fossiliferous clay that becomes glauconitic, marine, and fossiliferous at depth. The limestone in figure 2 represents the Ocala Limestone; the underlying sand represents the Clinchfield Sand in updip areas of the Coastal Plain. Below the Clinchfield Sand, geologically older deposits of the Lisbon Formation occur.

LeGrand $(1962$, p. 28$)$ described the then unnamed sand immediately underlying the Ocala Limestone as a "fine to medium-grained sand [having] little or no interstitial clay ***." According to Pickering $(1970$, p. 7,8$)$ the Clinchfield Sand is a medium-grained well-sorted poorly consolidated quartz sand having no observable crossbedding. He noted further that this sand grades upward into the overlying Ocala Limestone through a zone of sandy limestone lenses and sand. Screen analyses, by the Georgia Department of Mines, Mining and Geology of samples from 21 test holes drilled by the 


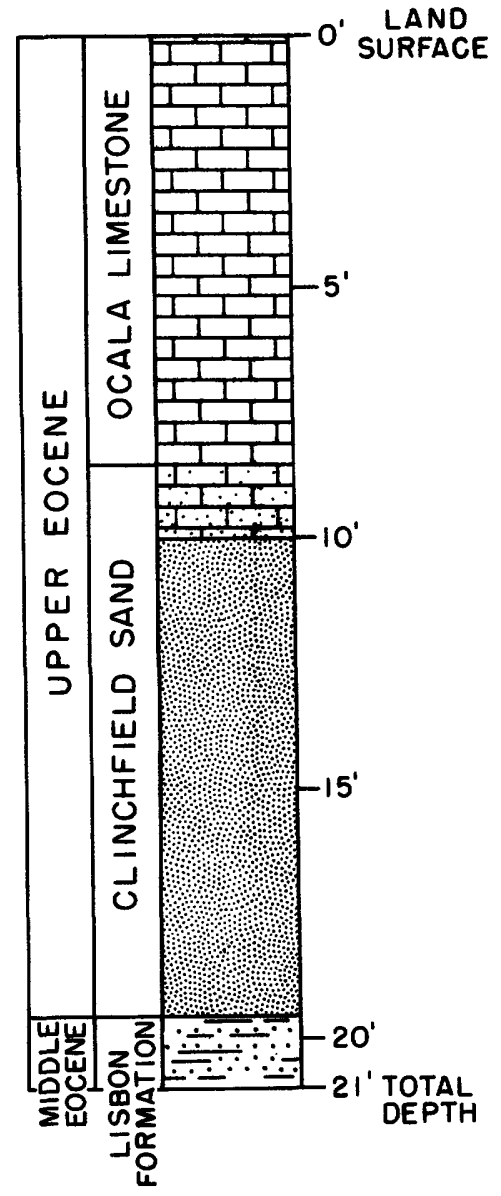

EXPLANATION

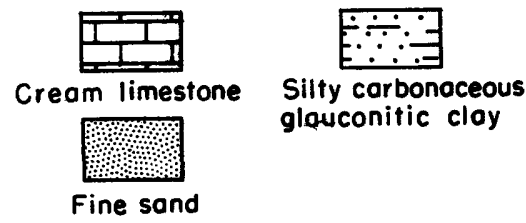

Fiaure 2.-Test hole in type section in west quarry of Penn-Dixie Cement Co., near Clinchfield, Ga.

Penn-Dixie Cement Co. in their west quarry, showed an even grain size for all samples tested. Examination of the sand through a binocular microscope shows the quartzose sand to be fine and very evenly grained, angular, sparsely glauconitic, calcareous, and somewhat fossiliferous. The sand contains bryozoan remains, fragments of molluscan shells (chiefly oyster), and some Foraminifera. 
The Clinchfield Sand varies in thickness both in outcrop and in the subsurface. Herrick (1961) logged thicknesses of the then unnamed sand of 16,18,22, and 35 feet from various wells in southwestern Georgia. Pickering (1970, fig. 5) included 34 feet of Clinchfield Sand in test hole 11 of the Penn-Dixie Cement Co., one of 21 test holes drilled in their west quarry. Cooke and Shearer $(1919, p .77)$ reported 25 feet of unnamed sand (now known to be the Clinchfield Sand) exposed beneath the Ocala Limestone in a gully on the south side of Rich Hill in Crawford County, central Georgia (fig. 1). Figure 2 shows an approximate thickness of 9 feet of Clinchfield Sand as determined from cuttings obtained from a test hole (GGS 994).

\section{"COOPER MARL"}

As noted by Cooke and MacNeil (1952, p. 26) and confirmed by the writer's sample, the deposit of "Cooper Marl" at Baldock, S.C., consists of a very sandy calcareous fossiliferous marl, decidedly carbonate in its overall composition. Presumably this marl overlies geologically older (that is, middle Eocene) sediments at this locality, though evidence proving this supposition has not been observed by the writer.

\section{DELLET SAND MEMBER OF MOODYS BRANCH FORMATION}

\section{AREAL EXTENT}

The Dellet Sand Member of the Moodys Branch Formation extends across Alabama to the Chattahoochee River at a point where Alabama, Florida, and Georgia meet. (See Huddlestun and Toulmin, 1965, fig. 2.) From this point the Moodys Branch equivalent, the Clinchfield Sand, extends eastward across Georgia to the Savannah River (fig. 1).

\section{LITHOLOGY}

Figure 3 shows the type section, which includes 2.2 feet of the Dellet Sand Member of the Moodys Branch Formation, at Claiborne Bluff, Ala. According to Stenzel $(1952$, p. 58, 59) the base of the Moodys Branch Formation at Claiborne Bluff consists of "friable and slightly tough, light-grayish, rust-brown massive, argillaceous, glauconitic, fossiliferous, fine-grained sand ***" to which he has given the name Dellet Sand Member, after the Dellet mansion, a "well-known landmark" in the nearby town of Claiborne, Ala. Stenzel further showed this sand as overlying the Gosport Formation of middle Eocene age and directly underlying the "Scutella bed" of the Moodys Branch 
AGE AND CORRELATION, CLINCHFIELD SAND, GEORGIA

\begin{tabular}{|c|c|c|c|c|c|}
\hline$\frac{\stackrel{\sim}{\tilde{m}}}{\stackrel{\sim}{\sim}}$ & 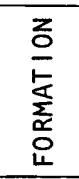 & 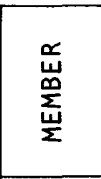 & LITHOLOGY & 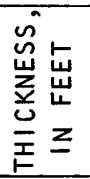 & DESCRIPTION \\
\hline \multirow{5}{*}{ 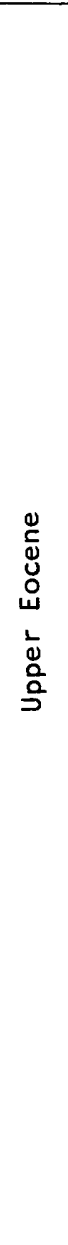 } & \multirow{3}{*}{$\begin{array}{l}\frac{\lambda}{0} \\
\\
8 \\
\stackrel{N}{N} \\
>\end{array}$} & \multirow{3}{*}{ 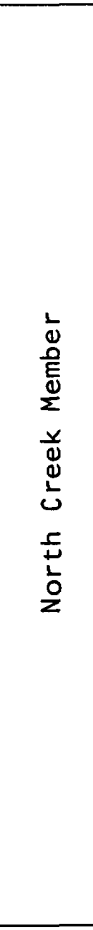 } & 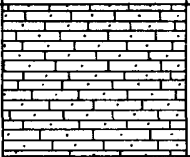 & 1.9 & $\begin{array}{l}\text { Hard cream sandy glauconitic } \\
\text { limestone }\end{array}$ \\
\hline & & & 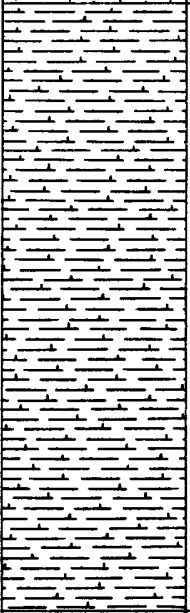 & 6.5 & Soft glauconitic marl \\
\hline & & & 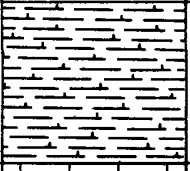 & 1.9 & Indurated glauconitic marl \\
\hline & \multirow{2}{*}{ 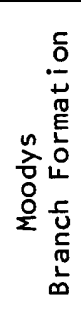 } & 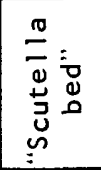 & | & 1.8 & Hard glauconitic limestone \\
\hline & & 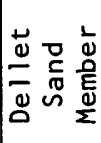 & & 2.2 & Gray glauconitic fine sand \\
\hline \multirow{2}{*}{ 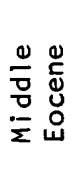 } & \multirow{2}{*}{ 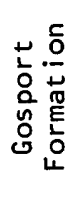 } & & $\because 4$ & $\begin{array}{l}0.06- \\
0.07\end{array}$ & Brown glauconitic coarse sand \\
\hline & & & $\begin{array}{l}\Rightarrow \approx A \\
\Rightarrow \approx A\end{array}$ & 11.7 & Brownish-gray shale \\
\hline
\end{tabular}

Figure 3.-Jackson-Claiborne section at Claiborne Bluff, Monroe County, Ala. (Modified from Stenzel, 1952). 
Formation ${ }^{4}$ of late Eocene age. As will be shown below by means of paleontologic evidence, it is the writer's conclusion that Stenzel's Dellet Sand is the stratigraphic equivalent (in part) of the deposit reported by Cushman and Todd (1945) as Moodys Branch Formation.

\section{ECOLOGY}

\section{POPULATION}

Foraminifera identified comprised 58 species and 36 genera in the material filling the oyster from the Clinchfield Sand from Clinchfield, Ga.; 99 species and 48 genera in the sandy marl from Baldock, S.C.; and 82 species and 41 genera in the Dellet Sand Member from Claiborne Bluff, Ala. Table 1 lists the species from these three localities, which are shown in figure 1.

\section{FAUNAL GHARACTERISTICS}

In summarizing the information on the ecology of the faunas listed in table 1 , the writer has used the following criteria developed by Phleger (1960, p. 257) :

1. The faunas at all three localities are predominantly benthonic in character. The ratios of planktonic to benthonic forms at the three localities were extremely low, amounting to 0.02 at Clinchfield, 0.04 at Baldock, and 0.02 at Claiborne Bluff.

2. In these three faunas, the ratios of arenaceous forms to total populations were estimated to be 0.15 at Clinchfield, 0.12 at Baldock, and 0.01 at Claiborne Bluff. These ratios indicate a preponderance of calcareous forms at each of the three localities analyzed.

3. Although the faunas at all three localities consisted predominantly of "smaller" Foraminifera, significantly, some larger ones belonging to the genera Lepidocyclina and Gypsina were observed at Clinchfield and Baldock. Specimens belonging to the genus Asterocyclina were also found at Clinchfield.

4. The types of preservation that prevailed at these localities are another important feature of these faunas. The tests of all forms at Clinchfield and the majority of those at Baldock have apparently been altered since deposition. Hence, at these two localities the tests are now cream colored, somewhat chalky, and distinctly nonvitreous. By contrast the fauna at Claiborne Bluff is composed of individuals having unaltered calcareous vitreous tests.

\footnotetext{
4 The Moodys Branch Formation was adopted to replace Moodys Marl in Mississippi. The formation underlies the Ocala Limestone in Alabama and Georgia.
} 
TABLE 1.-Foraminifera of the Clinchfield Sand at Clinchfield, Ga., and its equivalents at Baldock, S.C., Claiborne Bluff, Ala., and Jackson, Miss.

[Moodys Branch Formation at Jackson, Miss.: Type locality; reported by Cushman and Todd (1945)]

\begin{tabular}{|c|c|c|c|c|}
\hline Foraminifera & $\begin{array}{c}\text { Clinchfield } \\
\text { Sand at } \\
\text { Clinchfield, } \\
\text { Ga. }\end{array}$ & $\begin{array}{l}\text { "Cooper } \\
\text { Marl" at } \\
\text { Baldock, } \\
\text { S.C. }\end{array}$ & $\begin{array}{l}\text { Dellet Sand } \\
\text { Member of } \\
\text { Moodys Branch } \\
\text { Formation at } \\
\text { Claiborne Bluff, }\end{array}$ & $\begin{array}{l}\text { Moodys } \\
\text { Branch } \\
\text { Formation } \\
\text { at Jackson, } \\
\text { Miss. }\end{array}$ \\
\hline
\end{tabular}

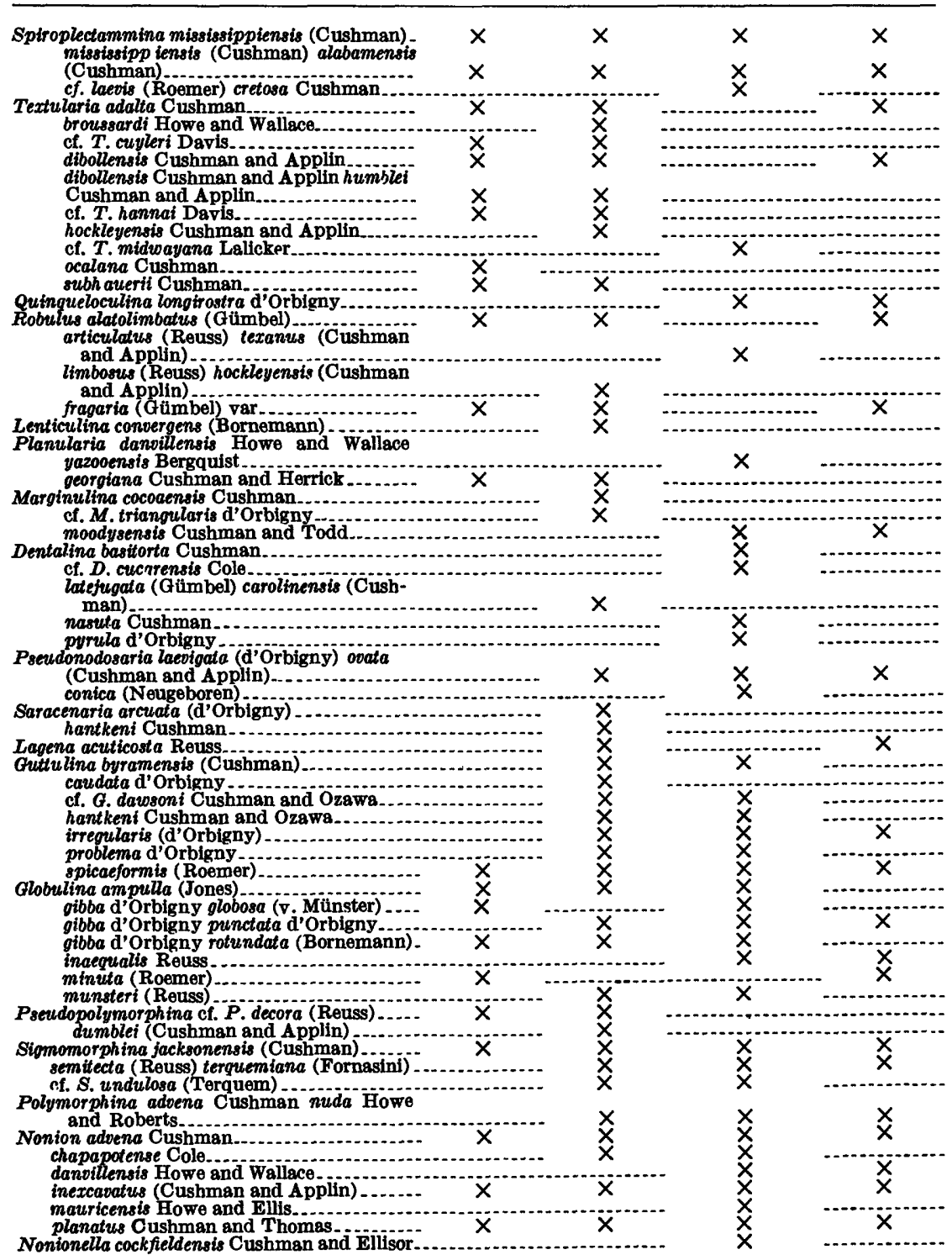


TABLE 1.-Foraminifera of the Clinchfield Sand at Clinchfield, Ga., and its equivalents at Baldock, S.C., Claiborne Bluff, Ala., and Jackson, Miss.-Continued

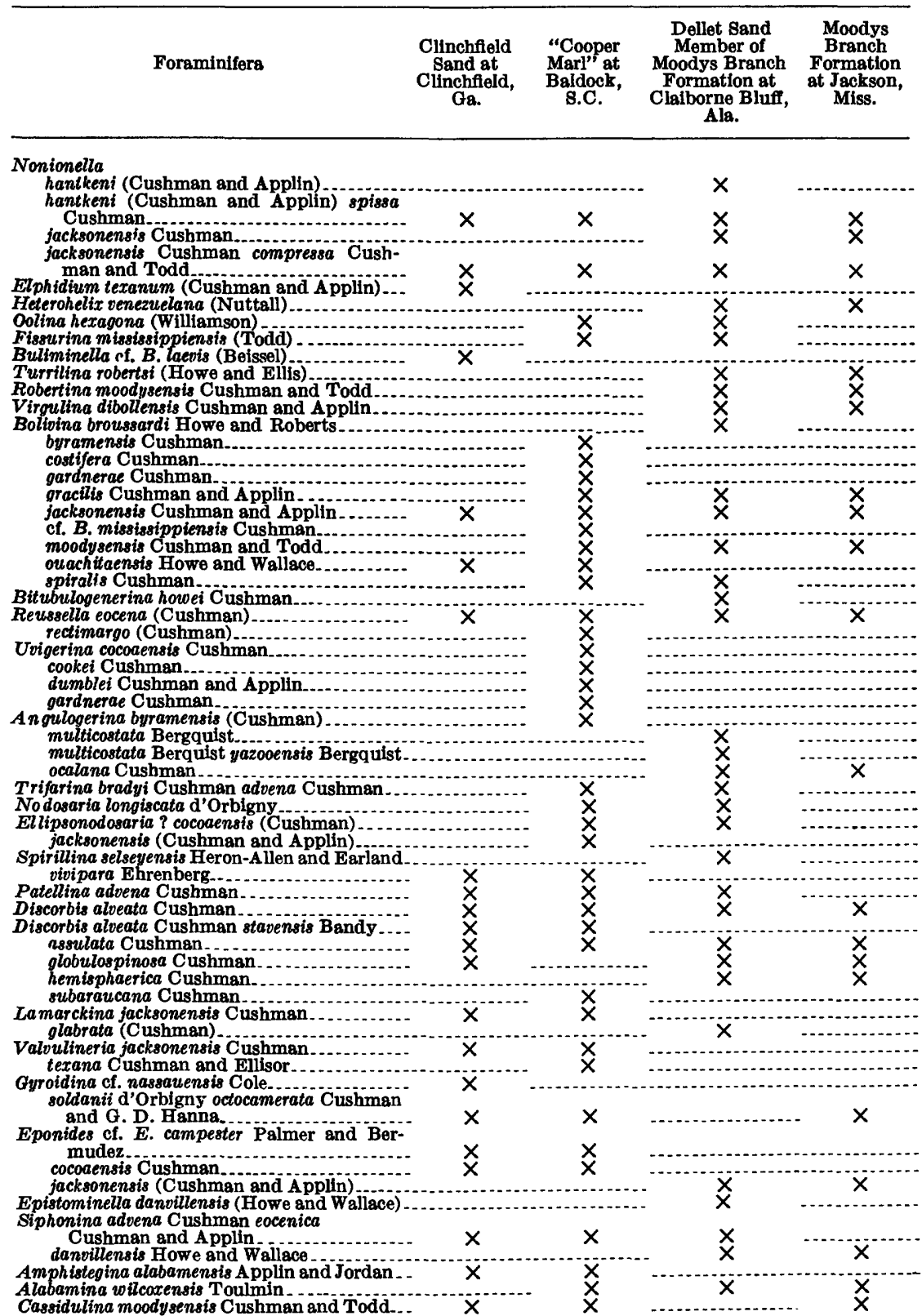


TABLE 1.-Foraminifera of the Clinchfield Sand at Clinchfield, Ga., and its equivalents at Baldock, S.C., Claiborne Bluff, Ala., and Jackson, Miss.-Continued

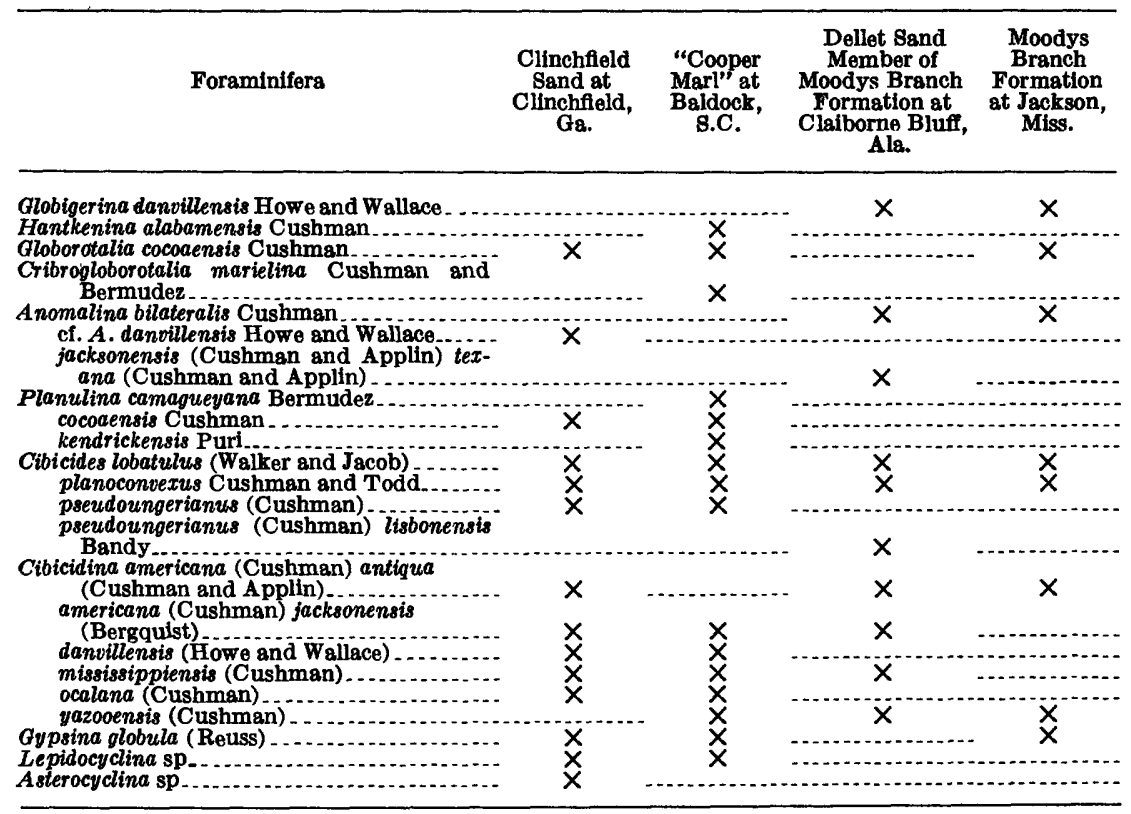

\section{DEPOSITIONAL ENVIRONMENT}

The types of preservation and the kinds of species occurring at the three localities allow deductions regarding the environment under which these strata were deposited. The sediments at Clinchfield and Baldock were deposited under definitely carbonate conditions as compared with a relatively carbonate-free environment at Claiborne Bluff. Stated another way, the clastic noncarbonate sediments of our western gulf coast region become increasingly more carbonate in an easterly direction, changing to limestone at the point where Alabama, Georgia, and Florida meet. A fuller description of this change in facies was illustrated by Huddlestun and Toulmin (1965, fig. 2).

In explaining such a change in facies on a regional scale, Cheetham $(1963$, p. 33, 35) pointed out that the sediments bordering the eastern gulf coast from the Mississippi-Alabama border to the AlabamaGeorgia-Florida junction, including the deposits at Claiborne Bluff, Ala., represent a "shelf phase" of sedimentation-that is, strata that were deposited on the continental shelf in fairly shallow marine water 
ranging from 100 to 300 feet in depth. Eastward from this point of juncture, however, geologically equivalent strata represent a "bank phase" 5 - that is, carbonate rock that was deposited on a submarine plateau in marine water not exceeding 150 feet in depth.

In view of the above statement, it seems evident that the deposits and their contained faunas at Clinchfield and Baldock represent shallow littoral, reeflike conditions in which the sea doubtless did not exceed 15-30 feet in depth, if that much. Moreover, since the microfossils at Clinchfield were obtained from a thick-shelled oyster occurring in a fossil reef, they must have been deposited in extremely shallow water-in the zone between low and high tides or even in the zone of wave action itself. However, at Claiborne Bluff, as suggested by the character of the fossils and the noncarbonate nature of the deposit, conditions were somewhat different. Here sediments were deposited on the continental shelf in fairly shallow carbonate-free marine water which was probably not much deeper than 75-90 feet. Owing to the presence of Quinqueloculina, a shallow-water form, as well as coarsegrained phosphatic inclusions found near the base of the Dellet Sand Member, it is thought that this shelf area, at best, did not exceed 150 feet in depth.

\section{GEOLOGIC AGE}

Probably the first to concern themselves with the age of the sand at the quarry near Clinchfield were Veatch and Stephenson (1911, p. 303), who considered it as being of questionable Jackson age. Cooke and Shearer (1919, p. 77) placed the sand in the Barnwell Formation, regarding it as late Eocene in age. Cooke (1939) considered the Gosport Sand of Alabama to be the equivalent of the Moodys Marl (of former usage) and, therefore, of late Eocene age.

MacNeil (1944, p. 32, 33) placed the sand at the Clinchfield locality in the late Eocene, regarding it as the equivalent of the Gosport Sand of Alabama. MacNeil (1947a) later made the same correlation but at this time considered the Gosport Sand to be late middle Eocene in age rather than late Eocene. Subsequently he correctly correlated this sand with the basal unit of the Moodys Branch Formation ("Scutella bed") of Alabama (MacNeil, 1947b).

Herrick (1961) and LeGrand (1962) considered the basal sand at the Clinchfield locality to be the equivalent of the Gosport Sand of Alabama and hence of late middle Eocene age. In Lee and Sumter Counties, Owen $(1963$, p. 35) correctly placed the sand in the basal part of the Ocala Limestone, as did Carver (1966). Herrick and Counts

\footnotetext{
5 As noted by Cheetham, Vaughan (1910, p. 150-155) was the first to call attention to this type of sedimentation in a carbonate environment as related to the Ocala Limestone.
} 
(1968, p. 28, 29) regarded the sand as late Eocene (Jackson) in age and included it as the lower unit of Cooke's Tivola Tongue ${ }^{6}$ of the Ocala Limestone.

The early late Eocene age of the microfaunas at the three localities is believed to be established through the presence of an appreciable number of identical species reported by Cushman and Todd (1945) from the Moodys Branch Formation at its type locality in Jackson, Miss. (table 1). A significant number of species occurring at the type locality of the Moodys Branch Formation also occurs at each of the three localities-26 species at Clinchfield, 33 at Baldock, and 41 at Claiborne Bluff. That more identical species were found at Claiborne Bluff as compared with the other two localities is not surprising. The reason for this is twofold: (1) Claiborne Bluff is geographically nearer to Jackson, Miss., and (2) the beds containing the microfaunas at Claiborne Bluff, Ala., and Jackson, Miss., are clastic. Those at Clinchfield and Baldock are basically carbonate.

At Clinchfield, an early late Eocene age for this basal sand is further strengthened by the fact that it is underlain by deposits belonging to the Lisbon Formation of middle (Claiborne) Eocene age, as shown in figure 2. Fossil evidence in support of this was obtained from a bit sample taken from the Lisbon Formation at a depth of 20.5 feet in another test hole drilled approximately 300 feet away from the test hole shown in figure 2. The foraminiferal species identified from this bit sample include Textularia cf. T. hannai, Robulus limbosus hockleyensis, Guttulina irregularis, Globulina gibba, Sigmomorphina semitecta var., Polymorphina advena nuda, Nonion advena, $N$. inexcavatus, N. planatus, Reussella eocena, Angulogerina cooperensis, Trifarina bradyi var., Discorbis assulata, $D$. cf. $D$. yeguaensis, Valvulineria jacksonensis, Gyroidina soldamii var., Siphonina claibornensis, Asterigerina cf. A. texana, Alabamina atlantisae, Globorotalia cocoaensis, Cibicidina americana antiqua, C. danvillensis, $C$. mississippiensis, Cibicides lobatulus, $C$. pseudonongerianus lisbonensis, and $C$. westi. Of the species listed above, $C i b i c i d e s$ pseudoungerianus lisbonensis and $C$. westi have never been observed by the writer in beds younger than middle Eocene in Georgia.

The middle Eocene age of the beds immediately underlying the Clinchfield Sand further suggests that the Gosport Sand, as such, does not exist at this locality. If the Gosport Sand were present in Georgia,

\footnotetext{
The name Tivola Tongue was applied by Cooke and Shearer $(1919$, p. 56) to the updip Ocala Limestone as it occurs east of the Flint River. The type locality for the Tivola Tongue is the east quarry of the Penn-Dixie Cement Co., 0.2 mile south of Clinchfield, Ga., on the east side of U.S. Highway 341. On the Perry (15-minute) quadrangle this locality is at the intersection of the coordinates long $83^{\circ} 37^{\prime} 57^{\prime \prime}$ and lat $32^{\circ} 24^{\prime} 13^{\prime \prime}$.
} 
the logical place in which to look for it in outcrops would be in southwestern Georgia between the Chattahoochee River and Clinchfieldfor example, in the vicinity of Howards Creek, on the Alabama side. However, at the Alabama locality, Toulmin and LaMoreaux (1963, p. 403, fig. 7) have shown that the Moodys Branch Formation rests directly upon the Lisbon Formation, the Gosport Sand apparently having pinched out before reaching the Chattahoochee River. On the basis of these observations, the Gosport cannot possibly be present at Clinchfield and, moreover, is doubtless absent at least in updip Georgia.

Other paleontologic evidence for an early late Eocene age of the Clinchfield Sand and the Dellet Sand Member of the Moodys Branch Formation is furnished by the presence of certain molluscan fossils in these two units. Pickering $(1970$, p. 20) reported Periarchus lyelli pileussinensis (Ravenel) and P.quinquefarius (Say) from the Clinchfield Sand at the Clinchfield locality. Huddlestun and Toulmin (1963, p. 403) reported Periarchus lyelli (Conrad) and Chlamys deshayesii (Lea) from the basal part (bed 42) of the Moodys Branch Formation (equivalent to Clinchfield Sand in Georgia) in an exposure along the Chattahoochee River in southeastern Alabama. However, as far as the writer is aware, $C$. deshayseii has not been reported from the Clinchfield Sand in Georgia. From the Dellet Sand Member at Claiborne Bluff, Ala., Stenzel (1952, p. 41) reported Periarchus lyelli, Crassatella n. sp., Chlamys deshayesii, and Flabellum sp., of which he regarded $C$. deshayesii as the guide fossil for the Dellet Sand Member.

\section{CORRELATION}

Evidence of the time equivalency of the faunas at these three localities is based on the following:

1. The faunas listed in table 1 contain at least 21 species that occur at each of the three localities. These species include, Spiroplectammina mississippiensis, S. mississippiensis alabamensis, Guttulina spicaeformis, Globulina ampulla, G. gibba rotundata, Sigmormorphina jacksonensis, Nonion advena, $N$. inexcavatus, $N$. planatus, Nonionella hantkeni spissa, N. jacksonensis compressa, Botivina jacksonensis, Reussella eocena, Patellina advena, Discorbis alveata, D. assulata, Siphonina advena eocenica, Cibicides lobatulus, C. planoconvexus, Cibicidina americana jacksonensis, and $C$. mississippiensis. The faunas occurring at Clinchfield and Baldock, however, are much more closely related to each other than they are to that of Claiborne Bluff. On a purely statistical basis, therefore, of the 58 species found at Clinchfield, 48 (83 percent) also occur at Baldock. In contrast, only 24 species 
(41 percent) of the species occurring at Clinchfield also are present at Claiborne Bluff. This same relationship is also suggested by the similarity of Clinchfield and Baldock ecologies as compared with that for Claiborne Bluff.

2. The faunas at the three localities contain 14 species (table 1) that also occur in the type Moodys Branch Formation which is early late Eocene (Jackson) in age.

\section{ORIGIN IN A TRANSGRESSIVE SEA}

The strata at the three localities represent deposits in a sea that transgressed the gulf and Atlantic coasts during early late Eocene (Jackson) time. Such a transgression resulted in a basal disconformity of regional proportions (Stenzel, 1939). In this regard, Stenzel (written commun., 1969) emphasized the importance of the published work cited above, "that this work was the first to prove that (1) the base of the Jackson Group rests on an erosion surface of marine origin and (2) that there is a regional disconformity at the base of the Jackson Group indicative of a widespread transgression at least in the area from Brazos County, Texas * * * into eastern Mississippi * * *." Subsequent to his earlier work, Stenzel (1952) traced this disconformity as far east as Claiborne Bluff, Ala. East of Claiborne Bluff, Huddlestun and Toulmin (1965, fig. 2) showed this contact as far east as the junction of Alabama, Florida, and Georgia. In Georgia convincing evidence of such a regional disconformity is furnished by LaMoreaux $(1946, \mathrm{pl} .1)$, whose geologic map of east-central Georgia contains abundant evidence of extensive Tertiary overlap of the Cretaceous and of the much older basement complex as well.

Variation in thickness of the Clinchfield Sand throughout its area of outcrop as well as in the subsurface is evidence of the transgressive nature of this sea in Georgia. At Claiborne Bluff, Ala., the occurrence of Nonionella cockfieldensis and Cibicides pseudoungerianus lisbonensis, guide fossils for the Yegua and Lisbon Formations, respectively, 'is regarded as possible evidence for such a transgression in southern Alabama. In the writer's opinion, these fossils may have been reworked from the underlying but geologically older Gosport Sand, and hence may not be indigenous to the Dellet Sand Member at Claiborne Bluff. In this regard a contrary view was expressed by Garrett (1936, p. 786), who reported Nonionella cockfieldensis from the basal Moodys Branch Forniation ${ }^{7}$ at Claiborne Bluff and regarded this foraminifer as indigenous as well as restricted to the strata. where found.

\footnotetext{
${ }^{2}$ In 1936 the Dellet Sand Member had not been recognized as a separate unit of the Moodys Branch Formation, hence Garrett's referring of Nonionella cockfleldensis to the Moodys Branch. Garrett 'ound this species in the basal part of the Moodys Branch Formation.
} 


\section{SUMMARY AND CONCLUSIONS}

The Clinchfield Sand is early late Eocene (Jackson) in age and represents the basal transgressive shoreline deposit of Cooke's Tivola Tongue of the Ocala Limestone. Species that indicate such an age include Textularia dibollensis humblei, Planularia georgiana, Nonion inexcavatus, $N$. planatus, Nonionella jacksonensis compressa, Discorbis alveata stavensis, and Cassidulina moodysensis (see table 1).

The basal upper Eocene (Jackson) deposits at the three localities are stratigraphically equivalent, though not identical. Such equivalency is indicated by the occurrence of an appreciable number of microfossils at each of the three localities as well as in the Moodys Branch Formation at its type locality in Jackson, Miss.

The deposits described from Clinchfield and Baldock represent a carbonate facies and hence are more closely related to each other than to those described from Claiborne Bluff. Fossils regarded as definite indicators of such a facies include Amphistegina alabamensis, Cribrogloborotalia marielina, Buliminella cf. B. laevis, Gypsina globula, and Lepidocyclina sp. (see table 1).

The Dellet Sand Member of the Moodys Branch Formation is present as far east as the Chattahoochee River (the Alabama-Georgia boundary), as shown by the reported occurrence of Chlamys deshayseii. The stratigraphic equivalent of the Gosport Sand of Alabama, of late middle Eocene (Claiborne) age, is not present at least in middip and updip parts of the Coastal Plain in Georgia.

The deposits at the three localities discussed in this report were deposited in a transgressive sea during early late Eocene (Jackson) time. This transgression followed a disconformity that is regional in scope.

\section{REFERENCES}

Carver, R. E., 1966, Stratigraphy of the Jackson Group (Eocene) in central Georgia : Southeastern Geology, v. 7, no. 2, p. 83-92, 3 figs.

Cheetham, A. H., 1963, Late Eocene zoogeography of the eastern gulf coast region : Geol. Soc. America Mem. 91, 113 p.

Cooke, C. W., 1936, Geology of the Coastal Plain of South Carolina: U.S. Geol. Survey Bull. 867, $196 \mathrm{p}$.

1939, Equivalence of the Gosport Sand to the Moodys Marl: Jour. Paleontology, v. 13, no. 1, p. 337-340.

Cooke, C. W., and MacNeil, F. S., 1952, Tertiary stratigraphy of South Carolina: U.S. Geol. Survey Prof. Paper 243-B, p. 19-29.

Cooke, C. W., and Shearer, H. K., 1919, Deposits of Claiborne and Jackson age in Georgia : U.S. Geol. Survey Prof. Paper 120, p. 41-81.

Cushman, J. A., and Todd, Ruth, 1945, Foraminifera of the type locality of the Moodys Marl Member of the Jackson Formation of Mississippi : Cushman Lab. Foram. Research Contr., v. 21, pt. 4, p. 79-105, pls. 13-16. 
Garrett, J. B., 1936, Occurrence of Nonionella cockfieldensis at Claiborne, Alabama : Jour. Paleontology, v. 10, no. 8, p. 785-786.

Herrick, S. M., 1961, Well logs of the Coastal Plain of Georgia : Georgia Geol. Survey Bull. 70, 462 p.

Herrick, S. M., and Counts, H. B., 1968, Late Tertiary stratigraphy of eastern Georgia : Georgia Geol. Soc. Guidebook, 3d Field Trip, 88 p., 2 figs.

Huddlestun, P. F., and Toulmin, L. D., 1965, Upper Eocene-lower Oligocene stratigraphy and paleontology in Alabama: Gulf Coast Assoc. Geol. Socs. Trans., v. 15, p. 155-159.

LaMoreaux, J. E., 1946, Geology and ground-water resources of the Coastal Plain of east-central Georgia : Georgia Geol. Survey Bull. 52, 173 p.

LeGrand, H. E., 1962, Geology and ground-water resources of the Macon area, Georgia : Georgia Geol. Survey Bull. 72, 69 p.

MacNeil, F. S., 1944, Southwestern Georgia field trip: Southeastern Geol. Soc. Guidebook, 2d Field Trip, p. 23-37.

1947a, Geologic map of the Tertiary and Quaternary formations of Georgia: U.S. Geol. Survey Oil and Gas Inv. Prelim. Map 72.

1947b, Correlation chart for the outcropping Tertiary formations of the eastern Gulf region: U.S. Geol. Survey Oil and Gas Inv. Prelim. Chart 29.

Owen, Vaux, 1963, Geology and ground-water resources of Lee and Sumter Counties, southwest Georgia: U.S. Geol. Survey Water-Supply Paper 1666, 70 p.

Phleger, F. B., 1960, Ecology and distribution of Recent Foraminifera: Baltimore, Md., Johns Hopkins Press, 297 p.

Pickering, S. M., Jr., 1970, Stratigraphy, paleontology, and economic geology of portions of Perry and Cochran quadrangles, Georgia : Georgia Geol. Survey Bull. 81, 67 p.

Stenzel, H. B., 1939, The Yegua problem: Texas Univ. Bull. 3945, p. 847-910, pls. 48-50.

1952, Transgression of the Jackson Group: Mississippi Geol. Soc. Guidebook, 9th Field Trip, p. 36-41, 58, 59, fig. 1.

Toulmin, L. D., and LaMoreaux, P. E., 1963, Stratigraphy along Chattahoochee River, connecting link between Atlantic and the Gulf Coastal Plains: Am. Assoc. Petroleum Geologists Bull., v. 47, no. 3, p. 385-404.

Vaughan, T. W., 1910, A contribution to the geologic history of the Floridian plateau : Carnegie Inst. Washington Pub. 133, Tortugas Lab. Papers, v. 4, p. 99-185.

Veatch, Otto, and Stephenson, L. W., 1911, Preliminary report on the geology of the Coastal Plain of Georgia : Georgia Geol. Survey Bull. 26, $466 \mathrm{p}$.

Vorhis, R. C., 1972, Geohydrology of Sumter, Dooly, Pulaski, Lee, Crisp, and Wilcox Counties, Georgia : U.S. Geol. Survey Hydrol. Inv. Atlas HA-435. (In press.) 


